\title{
Geomorfologia da Área de Proteção Ambiental do Rio Machado, Sul de Minas Gerais
}

\section{Geomorphology of the Environmental Protection Area of River Machado, Southern Minas Gerais}

Marta Felícia Marujo Ferreira Profa. Associada do Curso de Geografia e do Programa de Pós-Graduação em Geografia Universidade Federal de Alfenas - UNIFAL-MG, Brasil

martafelicia@uol.com.br

Beatriz Liara da Cruz

Discente do curso de Geografia da Universidade Federal de Alfenas - UNIFAL-MG, Brasil beatriz_liara@hotmail.com

Débora Haller da Silva Gregório

Discente do curso de Geografia da Universidade Federal de Alfenas - UNIFAL-MG, Brasil deborahallers@gmail.com

Deivison Samuel Pereira de Alfenas

Discente do curso de Geografia da Universidade Federal de Alfenas - UNIFAL-MG, Brasil deivisonsamuel@gmail.com

Guilherme Silva Pinto

Discente do curso de Geografia da Universidade Federal de Alfenas - UNIFAL-MG, Brasil guilhermesilpin@hotmail.com

Gustavo Sousa Marinho Discente do curso de Geografia da Universidade Federal de Alfenas - UNIFAL-MG, Brasil xmarinho.tp@gmail.com

\begin{abstract}
Resumo
A geomorfologia, como ciência da natureza, tem na cartografia geomorfológica, um dos métodos de pesquisa que permite compreender as relações espaciais, por meio de compartimentos geomorfológicos. A cartografia geomorfológica pode contribuir também com estudos de vulnerabilidade e potencialidade dos recursos do relevo. Este artigo tem como finalidade realizar o mapeamento geomorfológico da bacia do rio Machado, contemplando as análises morfográfica (qualitativa) e morfométrica (quantitativa). Estabeleceu-se uma proposta de compartimentação geomorfológica onde foi realizado o mapeamento de um conjunto de formas semelhantes do relevo, identificadas em função do índice de dissecação do relevo, formato dos topos, vertentes e vales. A área de estudo é a APA da bacia hidrográfica do rio Machado, que integra a bacia do Alto rio Grande, sul de Minas Gerais (Brasil), com superfície territorial de $1.016 \mathrm{~km}^{2}$. Os resultados comprovam a existência de seis compartimentos geomorfológicos definidos por controle litoestrutural, condicionando a dissecação do relevo da área. Entre o trecho superior do rio e o trecho médio, a presença de um degrau topográfico no perfil longitudinal do rio (Knickpoint), condiciona diferentes
\end{abstract}


compartimentos na bacia. No trecho superior, predominam o Compartimento de Colinas como superfície de cimeira, com altitudes que variam de 1134 a $1475 \mathrm{~m}$, no trecho médio, os Compartimentos de Morros com Encostas Suaves, Morros e Montanhas e Morrotes, aparecem em superfícies altimétricamente rebaixadas que variam de 759 a $1133 \mathrm{~m}$ e, no trecho inferior, o predomínio do Compartimento de Colinas em superfícies que variam de 759 a $969 \mathrm{~m}$. O Compartimento de Planície ocorrem nos fundos de vales amplos, com sedimentação intensa, vinculados ao rio Machado, principal nível de base da área, e de alguns tributários da margem direita e esquerda do rio.

Palavras-chave: Geomorfologia, Área de Proteção Ambiental do rio Machado, mapeamento geomorfológico, Minas Gerais.

\begin{abstract}
Geomorphology, as a science of nature, has in geomorphological cartography, one of the research methods that allows understanding the spatial relations, through geomorphological compartments. Geomorphological cartography can also contribute to studies of vulnerability and potentiality of relief resources. This article aimed to perform the geomorphological map of the Machado River basin, using morphographical (qualitative) and morphometrical (quantitative) analyzes. The geomorphological map units were performed using similar relief forms classification techniques, based on the relief dissection index, slope forms and valleys types. The study area of this research is part of the Machado River Environmental Protection Area (Machado River APA), which is part of the Alto Rio Grande basin, located in the South of the Minas Gerais state, Brazil, with a territorial area of $1,016 \mathrm{~km}^{2}$. The results showed that six geomorphological units were found in the Machado river basin, differing by lithological-structural controlling and surface relief dissection, showing great heterogeneity when analyzed at great scale. Among the upper and middle parts of the river, there is a topographic step in the longitudinal profile of the river (knickpoint), influencing different geomorphological compartments in the basin. In the upper part, in the hill unit predominates as a summit surface, with altitudes varying from 1,134 to $1,475 \mathrm{~m}$. In the middle part occurs hills and mountains unit and higher hills unit, located on altimetrically lowered surfaces, ranging from 759 to $1,133 \mathrm{~m}$. In the lower part, prevail the hill unit in surfaces that vary from 759 to $969 \mathrm{~m}$. The plains unit present large sedimentation areas, occurring in the bottom of broad valleys of the Machado River.
\end{abstract}

Keywords: Geomorphology, Machado River Environmental Protection Area, geomorphological mapping, Minas Gerais.

\title{
1. INTRODUÇÃO
}

A Geomorfologia, como parte da ciência geográfica, deve ser estudada a partir da tríade forma, materiais e processos. As formas, consideradas na esfera espacial, podem ser quantificadas por meio de parâmetros morfométricos e, qualificadas geometricamente. Os materiais (consistência, composição e propriedades), contidos nas formas, devem ser compreendidos por meio das relações entre rocha e relevo (resistência à erosão e ao intemperismo) e os processos, que promovem as transformações dos materiais e na mudança em novas formas, sejam atuais ou mesmo pretéritas. Assim, a morfodinâmica passa a ser um elemento decisivo no estudo da ocorrência e permanência 
dos processos, à qual é condicionada pelo clima, relevo, natureza da rocha, solos, cobertura vegetal, entre outros.

Tricart (1965) e Joly (1977), expoentes da escola francesa, contribuem na definição do objeto de estudo da geomorfologia. Nas palavras de Tricart (op. cit.) "a geomorfologia é a superfície de contato entre a parte sólida, a litosfera, e os meios que a envolvem - líquido e gasoso ou a epiderme da terra". Para Joly (op. cit.) a geomorfologia se ocupa com o estudo das formas do relevo terrestre, de sua gênese, de sua evolução no tempo e de suas relações no espaço. A partir destas definições, Rodrigues (1997) salienta que a geomorfologia pode ser considerada como ciência ponte devido ao seu objeto ser a epiderme da terra ou a superfície de contato, refletindo num equilíbrio dinâmico entre forças de natureza diversas.

A materialização da atividade humana sobre o relevo é assinalada como um conjunto de transformações que alteram o equilíbrio e a dinâmica dos processos naturais que modelam a superfície terrestre, interferindo também, nos processos pedogenéticos.

As diversas etapas de evolução do relevo nas últimas centenas de milhares de anos estão associadas a rápidas oscilações climáticas, somadas a aspectos da geodinâmica. A dinâmica dos processos (internos e/ou externos) deflagrada no passado, gerou um quadro fisiográfico revelado pelos grandes conjuntos de relevo, palco da dinâmica de processos atuais. A dialética imposta, implica em mudanças lentas e progressivas vinculadas a fatos naturais, como também, mudanças rápidas promovidas pela degradação humana (TRICART, 1976).

Para a geomorfologia aplicada, um dos principais métodos e produtos da pesquisa é a cartografia geomorfológica (RODRIGUES, 1997), que fornece a compreensão das relações espaciais, sintetizadas através dos compartimentos, permitindo abordagens geográficas como a vulnerabilidade e a potencialidade dos recursos do relevo. Rodrigues (op. cit.) argumenta que, análises envolvendo vulnerabilidades, fragilidades, potencialidades, aptidões do meio físico, podem ser produzidas mediante o levantamento de dados básicos, como morfométricos (quantitativos) e atributos morfográficos (qualitativos), que culminam na espacialização de compartimentos geomorfológicos, os quais podem auxiliar na compreensão das fragilidades e potencialidades da ocupação do relevo.

Ademais, o conhecimento geomorfológico pode evitar a ocorrência de impactos ambientais negativos, sobre o relevo. De acordo com Cunha (2003), a geomorfologia, entendida como o estudo das formas de relevo e dos processos responsáveis por sua elaboração, tem na cartografia geomorfológica um dos mais importantes veículos de comunicação e analise dos resultados obtidos, resolvendo uma série de problemas geomorfológicos práticos, além de evitar a ocorrência destes, principalmente através da indicação de áreas favoráveis ou desfavoráveis ao desenvolvimento das atividades humanas. 
Demek (1967) aponta que o mapeamento geomorfológico consiste em um dos principais métodos da pesquisa geomorfológica, já que promove a identificação e classificação do relevo. Entretanto, para denominarmos de carta geomorfológica, Tricart (1965) ressalta que se faz necessário a inserção de análises morfográficas (geometrias das formas), morfométricas (dados obtidos pela carta topográfica), morfogenéticas (natureza do material, formações superficiais e substrato) e análises morfocronológicas (formas atuais e formas herdadas de processo pretéritos). A mesma opinião é corroborada por Ross (1990), que afirma que o mapa geomorfológico deve contribuir com elementos da descrição do relevo, na identificação da natureza geomorfológica e na indicação da datação das formas de relevo.

Estudos de geomorfologia ambiental e de aplicação se ocupam em analisar os processos físicos naturais e explicar as mudanças que os ambientes naturais sofrem em função das demandas da sociedade. O conhecimento dos recursos existentes (relevo, solos, rochas, recursos hídricos, entre outros) de uma área, pode mitigar e evitar catástrofes em áreas de ocupação acelerada. Nas palavras de Hart (1986 apud Guerra e Marçal, 2006),

A Geomorfologia ambiental pode contribuir para solucionar problemas relacionados ao meio físico. Para isso, precisa conhecer a Geomorfologia Pura e conhecimentos relativos ao manejo ambiental, avaliação de recursos naturais, técnicas geomorfológicas de mapeamento, avaliação de paisagens etc. (GUERRA e MARÇAL, 2006, p. 21).

A relação entre natureza e sociedade tem sido abordada em muitos trabalhos que envolvem a Geografia. De acordo com Ross (2003), o apoio e suporte da geomorfologia na compreensão dos problemas socioambientais pode ser observado na produção de instrumentos técnicos de gestão por meio da execução de zoneamentos ambientais. Desse modo, conforme Rodrigues, [...] as cartas geomorfológicas constituem um dos principais instrumentos técnicos a serem analisados nas experiências de planejamento, visto que é a partir delas que outros instrumentos são criados, inclusive com nível de complexidade, de síntese e de interpretação maiores (RODRIGUES, 1997, p. 96)

Assim, um instrumento técnico produzido no âmbito da geomorfologia, e que auxilia na execução de projetos de planejamento, é o mapa de compartimentação topográfica/geomorfológica, denominado neste trabalho de mapa geomorfológico ou tipos de relevo ou unidades morfológicas ou padrões de formas semelhantes (3º táxon). Baseado em Ross (1992, p. 19) o $3^{\circ}$. táxon trata-se de "um conjunto de formas menores do relevo que apresentam distinções de aparência entre si em função da rugosidade topográfica ou índice de dissecação do relevo". É produzido e representado por diferentes padrões de formas, com características similares como declividade das vertentes, morfologia dos topos, dimensões interfluviais e entalhamento dos canais de drenagem. A execução deste mapeamento traz os diferentes níveis topográficos e as características do relevo, importantes para o processo de ocupação do relevo. Conforme Ross e Moroz (1996), 
[...] as formas diferenciadas do relevo decorrem da atuação simultânea e desigual das atividades climáticas de um lado e da estrutura da litosfera de outro, bem como a clareza de que tanto o clima quanto a estrutura não se comportam permanentemente sempre iguais, ou seja, ao longo do tempo e no espaço ambos continuamente se modificam (ROSS; MOROZ, 1996, p. 43).

Este trabalho, de caráter geomorfológico, a construção do mapa por meio da cartografia geomorfológica deverá subsidiar o planejamento ambiental dos espaços físico-territoriais da bacia hidrográfica do rio Machado. Poucos são os trabalhos que tratam da geomorfologia do sul de Minas Gerais, integrando critérios geomorfológicos à análise das formas de relevo. Ressalta-se a necessidade deste estudo pois, de acordo com Marques (1994), os relevos constituem os pisos sobre os quais se fixam as populações humanas e são desenvolvidas suas atividades, resultando, desta forma, em valores econômicos e sociais.

Com a finalidade de auxiliar no diagnóstico geoambiental da APA do rio Machado, este estudo propõe a realização do mapeamento geomorfológico da bacia do rio Machado, contemplando as análises morfográfica (qualitativa) e morfométrica (quantitativa). O mapa produzido servirá de base para estudos interdisciplinares, bem como para o plano de manejo da APA e para a administração pública dos municípios integrantes da bacia do rio Machado.

Este estudo serve de base para a gestão do território e para a ação de planejamento, ordenação ou monitoramento da bacia, devendo incorporar ainda, a análise dos diferentes componentes do ambiente, incluindo o meio físico-biótico, a ocupação humana, e as interações advindas destes componentes.

\section{MATERIAIS E MÉTODOS}

\subsection{A área de Estudo}

A área de estudo se insere na Área de Proteção Ambiental da Bacia Hidrográfica do rio Machado - APA do rio Machado, que integra a bacia do Alto rio Grande situando-se no sul do estado de Minas Gerais (Brasil), com superfície territorial de $1.016 \mathrm{~km}^{2}$. Abrange os municípios de Espírito Santo do Dourado, Congonhal, Ipuiúna, São João da Mata, Poço Fundo, Campestre, Machado, Alfenas, Paraguaçu e Fama (Figura 1).

As Unidades de Conservação, categoria APA, se encaixa no modelo de Unidade de Uso Sustentável. Insere-se em um grupo de Unidade de Conservação que visa compatibilizar a conservação da natureza com o uso sustentável dos recursos naturais. As atividades desenvolvidas na APA devem assegurar a perenidade dos recursos ambientais renováveis (MMA, 2000). Foi definida e estabelecida pela Lei 9.985, de 18 de julho de 2000, que trata do Sistema Nacional de Unidades de Conservação da Natureza (SNUC) (BRASIL, 2000). Foram concebidas um conjunto de unidades de 
conservação no âmbito federal, estadual e municipal com a finalidade de promover a gestão e o planejamento das Unidades de Conservação (UC).

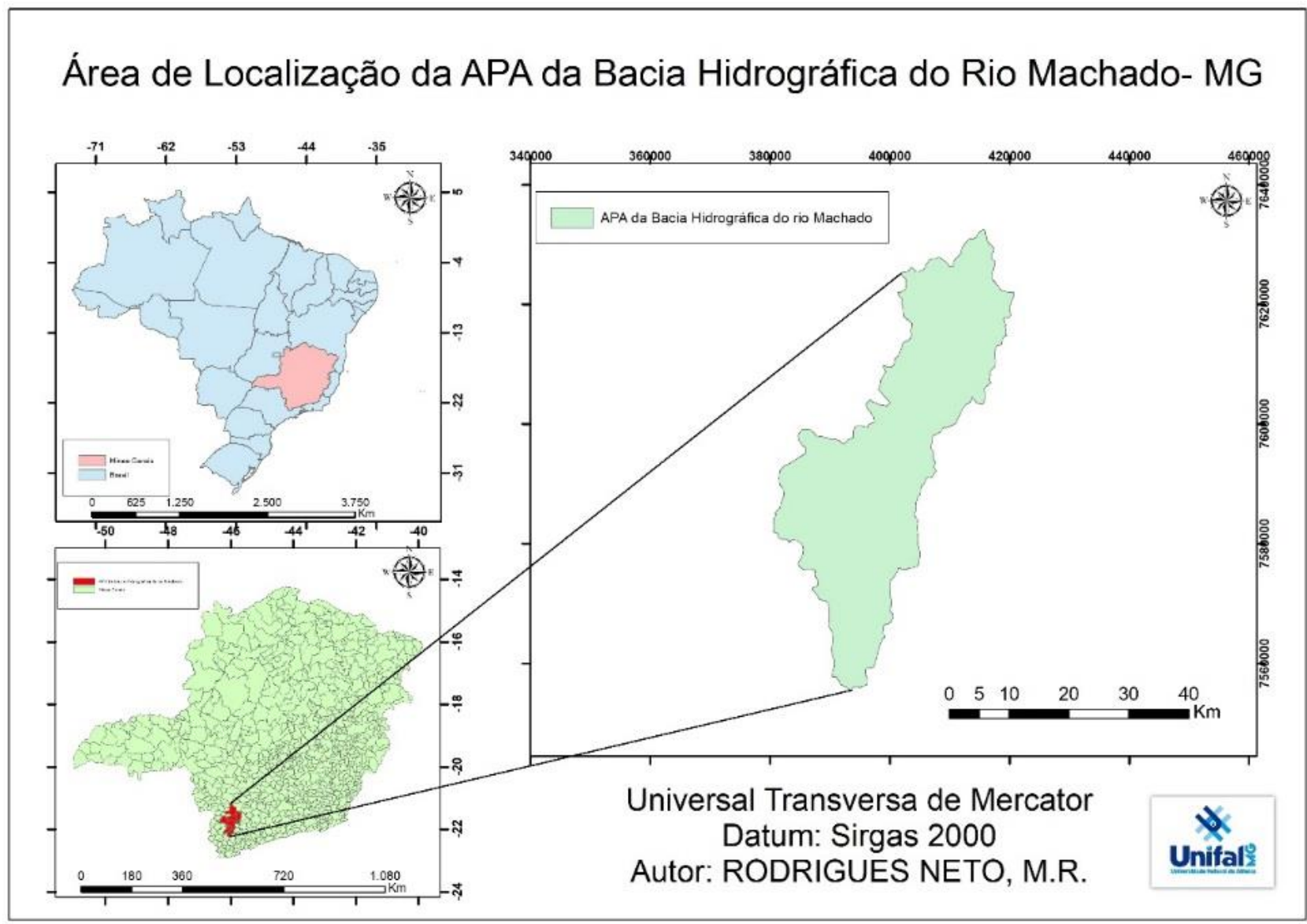

Figura 1 - Localização da área de estudo no Brasil e no Estado de Minas Gerais.

Fonte - Rodrigues Neto, 2018.

A área abrangida pela APA faz parte da subzona Planalto Sul de Minas que está compartimentada em três macro unidades geomorfológicas: Superfície do Alto rio Grande, Planalto de São Pedro de Caldas e Planalto de Poços de Caldas (CAVALCANTE, et al., 1979).

SAADI (1991) propõe uma subdivisão da região sul de Minas Gerais, baseada em dois fatores tectônicos: a intensidade do soerguimento mesozóico-cenozóico responsável pela intensidade de dissecação e pela energia do relevo; e a influência dos cinturões de cisalhamento como condicionantes da fragmentação do relevo em suas direções preferenciais. Com base nesses critérios o autor diferencia sete compartimentos morfoestruturais: Escarpa Meridional, Degrau Superior, Degrau Intermediário, Planalto de Caldas-Machado, Planalto de Madre de Deus de Minas, Corredor de Campo do Meio e Serras Quartzíticas. Dentro dessa compartimentação, a área integra o Planalto de Caldas-Machado. Conforme Saadi (op. cit.). 
[...] este planalto possui composição litológica constituída por rochas metamórficas de médio e alto grau e ausência de orientação tectônica preferencial. Ao sul, é condicionado pelas falhas do Cinturão Ouro Fino originando cristas de direções NE-SW e, ao norte, falhas do Cinturão Campo do Meio, responsáveis por um relevo de direção NW-SE. O planalto e as unidades menores de relevo mostram basculamento para NW (SAADI, 1991, p. 72).

A APA do rio Machado apresenta compartimentos geomorfológicos diversificados onde dominam um conjunto de relevos de morros e montanhas, morros com encostas suaves, morrotes, colinas e planícies. Altitudes menores em torno de 730m, estão associadas à planície do rio Machado, nível de base da área, e, as maiores altitudes, em torno de 1480m, acham-se em compartimentos de morros e montanhas e morros com encostas suaves, muitas vezes delimitados por escarpas dissecadas onde descem cursos d'água que se ligam ao rio Machado.

Estudos efetuados por Almeida (1997) mostram a ocorrência de três domínios litoestruturais: os domínios sul, central e norte. Parte da bacia do rio Machado, a jusante, situa-se no domínio sul, o qual é delimitado por extenso lineamento, a Zona de Cisalhamento Varginha (ZCV), de direção WNW-ESSE. As rochas deste domínio equivalem ao Complexo Varginha, constituído por rochas ortoderivadas de composição granítica, charnockitos e gnaisses com granada e sillimanita.

A vegetação é composta pela Mata Atlântica, principalmente nos municípios localizados mais a sul da APA; e pela transição da Mata Atlântica para o Cerrado, como pode ser observado no município de Alfenas. Em grande parte da bacia, o uso do solo mostra áreas de café formado e em formação, pastagens, culturas anuais diversificadas, áreas de vegetação natural de pequeno porte (Cerrado), vegetação natural de porte elevado como matas ciliares que acompanham cursos d'água, remanescentes de Mata Atlântica e Cerradão (ALVES et al., 2003).

O clima da área, geralmente tratados em estudos de âmbito regional, é o tropical de altitude (Cwa), com média anual de $19,6^{\circ} \mathrm{C}$, média máxima anual de $26,9^{\circ} \mathrm{C}$ e média mínima anual de $14,3^{\circ} \mathrm{C}$. As chuvas são distribuídas em duas estações, uma chuvosa, que ocorre no período de outubro a março, com índice pluviométrico anual em torno de $1500 \mathrm{~mm}$, e outra mais seca, de abril a setembro (CARDOSO, 2003).

De acordo com Alves et al. (2003) na região sul de Minas Gerais, a cafeicultura é responsável por cerca de $50 \%$ da produção do estado. Conforme os autores, "os municípios de Machado, Campestre e Poço Fundo, apresentam fatores ambientais favoráveis à produção de cafés de excelente qualidade, que estão aliados a sistemas de produção amplamente dominados pelos produtores locais". Ainda segundo os autores, “existem áreas com características fisiográficas favoráveis à produção de cafés especiais. Elas se destacam por suas elevadas altitudes variando entre 700 e 1.200 metros, temperatura amena, risco moderado de geadas e aptidão para produzir café de excelente qualidade" (p. 2). 
Em função da atividade agrícola, há cooperativas de grande importância regional, como a COOPFAM, localizada no munícipio de Poço Fundo, e a COOXUPÉ, que possui um núcleo em Alfenas.

\subsection{Procedimentos Metodológicos}

O desenvolvimento deste trabalho iniciou-se por meio de consulta bibliográfica sobre um dos principais métodos da pesquisa geomorfológica, a cartografia geomorfológica. Além disso, buscou-se levantar dados e informações disponíveis em cartas e mapas.

A geomorfologia tem sido referenciada como ferramenta valiosa nas investigações do meio físico, especialmente como componente importante para elucidar problemas socioambientais deflagrados pela atividade antrópica. A representação cartográfica do relevo constitui-se em um instrumento de análise importante tanto no campo quanto no gabinete, para avaliar e sintetizar as relações existentes entre fatos geomorfológicos e ações antrópicas sobre o relevo. Os procedimentos teórico-metodológicos adotados, relacionam-se a trabalhos de gabinete para a execução dos mapas temáticos e mapeamento dos compartimentos geomorfológicos como também, na realização de trabalhos de campo que ajudaram na checagem e definição dos compartimentos reconhecidos e mapeados em gabinete.

O material cartográfico utilizado foram cartas topográficas (Alfenas, Campestre, Ipuiuna, Machado, Poço Fundo, Pouso Alegre, Rio Capivari), escala 1:50.000 do IBGE, e cartas 1:250.000, folhas Guaratinguetá e Varginha, além de imagens de satélite do Google Earth e SRTM (Tabela 1). Estes materiais, possibilitaram a elaboração dos mapas geomorfológico, hipsométrico, clinográfico. Para a elaboração dos mapas foi utilizado o software ArcGIS 10.2.1. O fluxograma a seguir mostra a sequência metodológica adotada neste trabalho (Figura 2).

Para alcançar os objetivos propostos, o presente estudo se apoiou na metodologia delineada por Ab’ Sáber (1969), Pires Neto (1991), Ross (1990) e IPT (1981). Na compartimentação geomorfológica foi utilizada a metodologia de Pires Neto (1991) que compreende o mapeamento baseado na análise de tipos de relevo (DEMECK, 1967), também denominado complexo de formas de relevo (SPIRIDONOV, 1980) e unidades genéticas do relevo (VERSTAPPEN; VAN ZUIDAN, 1975). Esta unidade taxonômica corresponde a uma associação de formas de relevo, que leva em consideração os sistemas de interflúvios e vales, as condições litoestruturais, os condicionamentos morfoestruturais, os agentes morfogenéticos e a história evolutiva, bem como seus atributos morfométricos e morfográficos.

Foi realizado o mapeamento de um conjunto de formas semelhantes do relevo, identificadas em função do índice de dissecação do relevo, formato dos topos, vertentes e vales, segundo Ross 
(1992). O resultado final, é o mapa geomorfológico com a compartimentação topográfica que servirá de subsídio à gestão e ao planejamento da bacia hidrográfica do rio Machado.

Tabela 1 - Especificações das cartas topográficas e do material de sensoriamento remoto utilizados no desenvolvimento da pesquisa.

\begin{tabular}{cccc}
\hline Material & Articulação & Escala & Órgão Executor \\
\hline Campestre & SF-23-V-D-IV-2 & $1: 50.000$ & IBGE \\
Ipuíuna & SF-23-Y-B-I-2 & $1: 50.000$ & IBGE \\
Machado & SF-23-I-III-I & $1: 50.000$ & IBGE \\
Paço Fundo & SF-23-V-D-V-3 & $1: 50.000$ & IBGE \\
Pouso Alegre & SF-23-Y-B-II-1 & $1: 50.000$ & IBGE \\
Rio Capivari & SF-23-V-D-IV-4 & $1: 50.000$ & IBGE \\
Alfenas & SF-23-I-I-3 & $1: 50.000$ & IBGE \\
Varginha & SF-23-Y-B & $1: 50.000$ & IBGE \\
Fotografias Aéreas & 1980 & $1: 60.000$ & USAF \\
Imagens SRTM & 2018 & - & USGS (2018) \\
Imagens Google Earth & 2018 & - & Google Earth (2018) \\
\hline
\end{tabular}

Fonte - Autores, 2019.

Os tipos de relevo mapeados foram: relevos de denudação (morros e montanhas, morros com encostas suaves, morrotes, colinas), relevos de agradação (planícies fluviais), além de mapear os tipos de topos como os arredondados/convexos, estreitos/agudos e os tipos de vales: em "V", assimétricos, de fundo chato. A partir da delimitação de sub-bacias pertencentes a bacia do rio Machado, foram calculados a amplitude e declividade das diferentes formas de relevo, considerando os pontos cotados (topos) e o nível de base dos rios de cada sub-bacia. Assim, foram traçados o $3^{\circ}$. táxon (ROSS, 1992), que correspondem as unidades dos padrões de formas semelhantes do relevo, identificadas em função do índice de dissecação do relevo, formato dos topos, vertentes e vales (Tabela 2).

As atividades realizadas durante os trabalhos de campo foram fundamentais para a confirmação do mapeamento dos compartimentos geomorfológicos na APA, e, sobretudo, para a checagem e descrição local dos diferentes processos erosivos mapeados. Os trabalhos de campo foram desenvolvidos nos meses de novembro de 2017 e janeiro de 2018, para a checagem dos compartimentos geomorfológicos, tendo o apoio do Instituto Estadual de Florestas (IEF) e dos recursos cartográficos e de material técnico da Universidade Federal de Alfenas. 


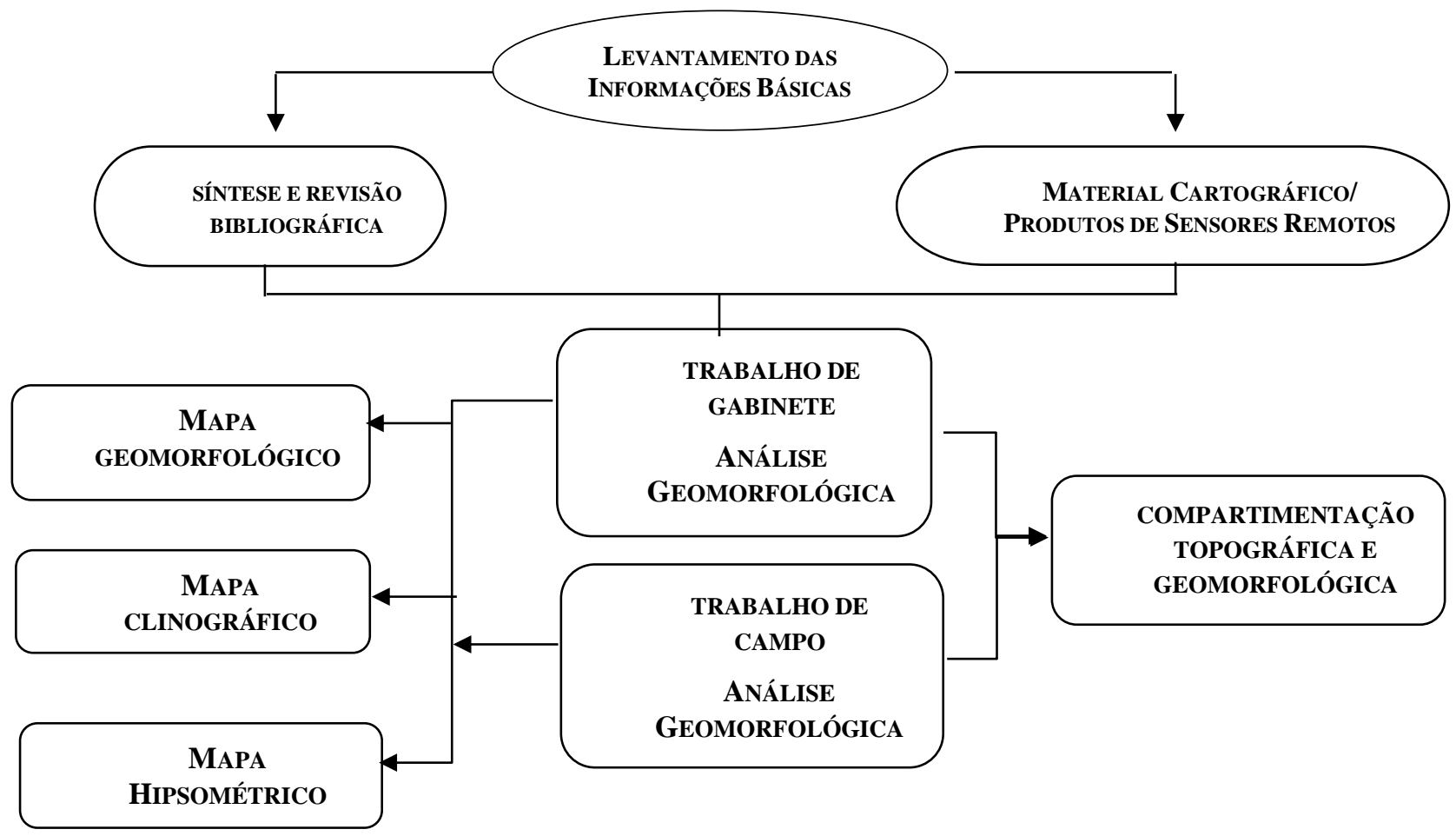

Figura 2 - Sequência metodológica adotada no trabalho.

Fonte - Autores, 2019.

Tabela 2 - Características Morfométricas dos principais Tipos de Relevo.

\begin{tabular}{lccc}
\hline \multicolumn{1}{c}{ TIPO DE RELEVO } & AMPLITUDE & DECLIVIDADE & PADRÕ ES DE CORES \\
\hline Escarpa Dissecada (E) & $>350 \mathrm{~m}$ & $>20 \%$ & Marrom \\
Morros e Montanhas (MMh) & $>300 \mathrm{~m}$ & $>15 \%$ & Roxo \\
Morros com encostas suaves (M) & 100 a $300 \mathrm{~m}$ & $5-15 \%$ & Rosa \\
Morrotes (Mt) & $<100 \mathrm{~m}$ & $>15 \%$ & Cinza \\
Colinas (C) & $<100 \mathrm{~m}$ & 0 a $15 \%$ & Verde claro \\
Planícies Fluviais (P) & - & - & Amarelo \\
\hline
\end{tabular}

Fonte - Modificado de PIRES NETO (1991).

\section{RESULTADOS E DISCUSSÃO}

A análise geomorfológica da bacia hidrográfica do rio Machado se baseia na caracterização dos compartimentos geomorfológicos que, quando avaliados detalhadamente, mostram grande heterogeneidade. A bacia do rio Machado tem suas cabeceiras alojadas no reverso da Serra do Cervo, ao sul, e Serra do Navio, da Jangada e do Cantagalo a leste, apresenta geometria alongada, tendo uma rede hidrográfica densa, marcada por forte controle estrutural. Este controle é definido na bacia pela presença de padrões de drenagem do tipo dendrítico, que ocorre em grande parte da área, treliça direcional, a montante da bacia, e o padrão subdendrítico, em setores onde há forte condicionamento litoestrutural. 
Apoiado na análise morfoestrutural realizada por Saadi (1991) sobre o Planalto de CaldasMachado onde se insere a bacia do rio Machado, o presente trabalho determinou a presença de compartimentos geomorfológicos que são definidos por controle litoestrutural, condicionando a dissecação do relevo da área. De acordo com pesquisas realizadas por Fiori (1979) e Artur (1988), o controle litológico na bacia é gerado pelo Complexo Pinhal, Complexo Amparo e Complexo Silvianópolis com rochas do tipo Migmatitos com estruturas diversas granodioríticos a predominantemente graníticos rosados, cinzentos e esbranquiçados, Migmatitos de estruturas diversas e frequentes Gnáisses migmatíticos (ARTUR, 1988) e Gnaisses fitados e bandeados (FIORI, 1979) e Granulitos, respectivamente.

De acordo com Artur (1988), alguns trechos próximos a Machado, associados ao compartimento de Morros com Encostas Suaves, mostram a ocorrência de Gnaisses granulíticos predominantemente Charnockíticos e Enderbíticos (Complexo Guaxupé). Os compartimentos propostos foram agrupados em unidades de padrões de formas semelhantes (índice de dissecação, forma dos topos, vertentes e vales) sendo que, a dissecação do relevo e a amplitude topográfica, são elementos que permitiram a definição de seis compartimentos de relevo, a saber: Escarpas, Morros e Montanhas, Morros com Encostas Suaves, Morrotes, Colinas e Planícies (Figura 3).

A Figura 4 representa o diagrama da proporção em área ocupada por compartimento geomorfológico na APA da bacia do rio Machado. Analisando-se a Figura 5 observamos que os compartimentos Colinas (26\%) Planície (24\%) e Morros com Encostas Suaves (21\%) ocupam a maior parte da APA do rio Machado. Os compartimentos com menor extensão na APA são Escarpa (17\%), Morrotes (10\%) e Morros e Montanhas (2\%).

A análise geomorfológica apresentada neste estudo, além do mapa geomorfológico que definiu os principais compartimentos da bacia, teve como apoio a construção dos mapas hipsométrico e clinográfico. As altitudes maiores (entre 1.134 a $1.475 \mathrm{~m}$ ) ocorrem no trecho superior do rio Machado enquanto que as menores (entre 750 a 1.134m), nos trechos médio e inferior. De maneira geral estes mapas mostram uma mudança significativa no trecho médio da bacia do rio Machado, onde a faixa altimétrica de 750 a $1.134 \mathrm{~m}$ marca a presença de um degrau topográfico (knickpoints) que, ao mesmo tempo, corresponde a uma faixa de declives que variam de 36 a $60 \%$. Os trechos superior e inferior da bacia mostram a presença dominante do Compartimento de Colinas e do Compartimento de Morrotes, mostrando vertentes com declives menores, variando de 0 a $15 \%$ e de 15 a $25 \%$. 


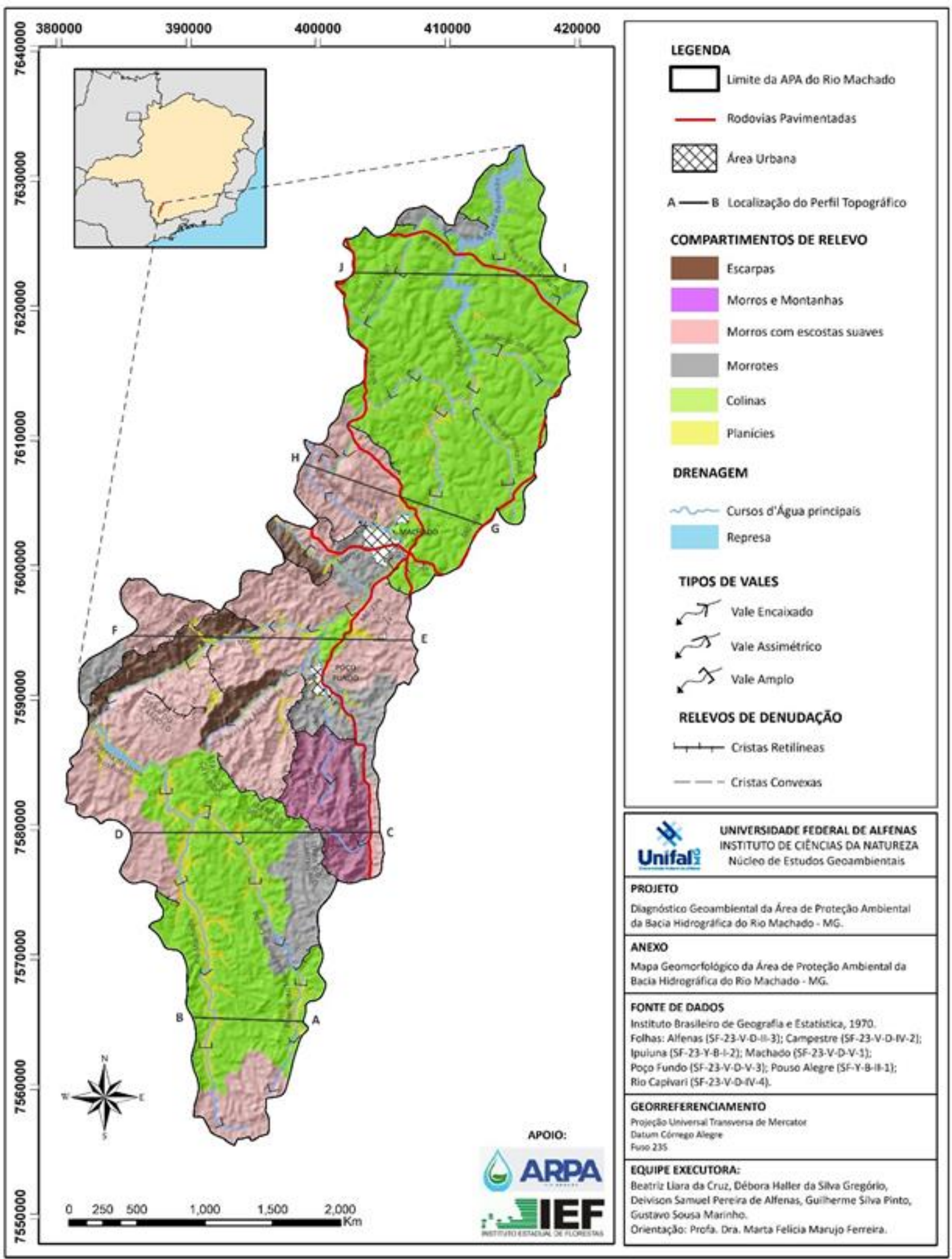

Figura 3 - Compartimentos geomorfológicos da APA do rio Machado - MG e Perfis topográficos localizados no mapa. Fonte - Autores, 2019. 


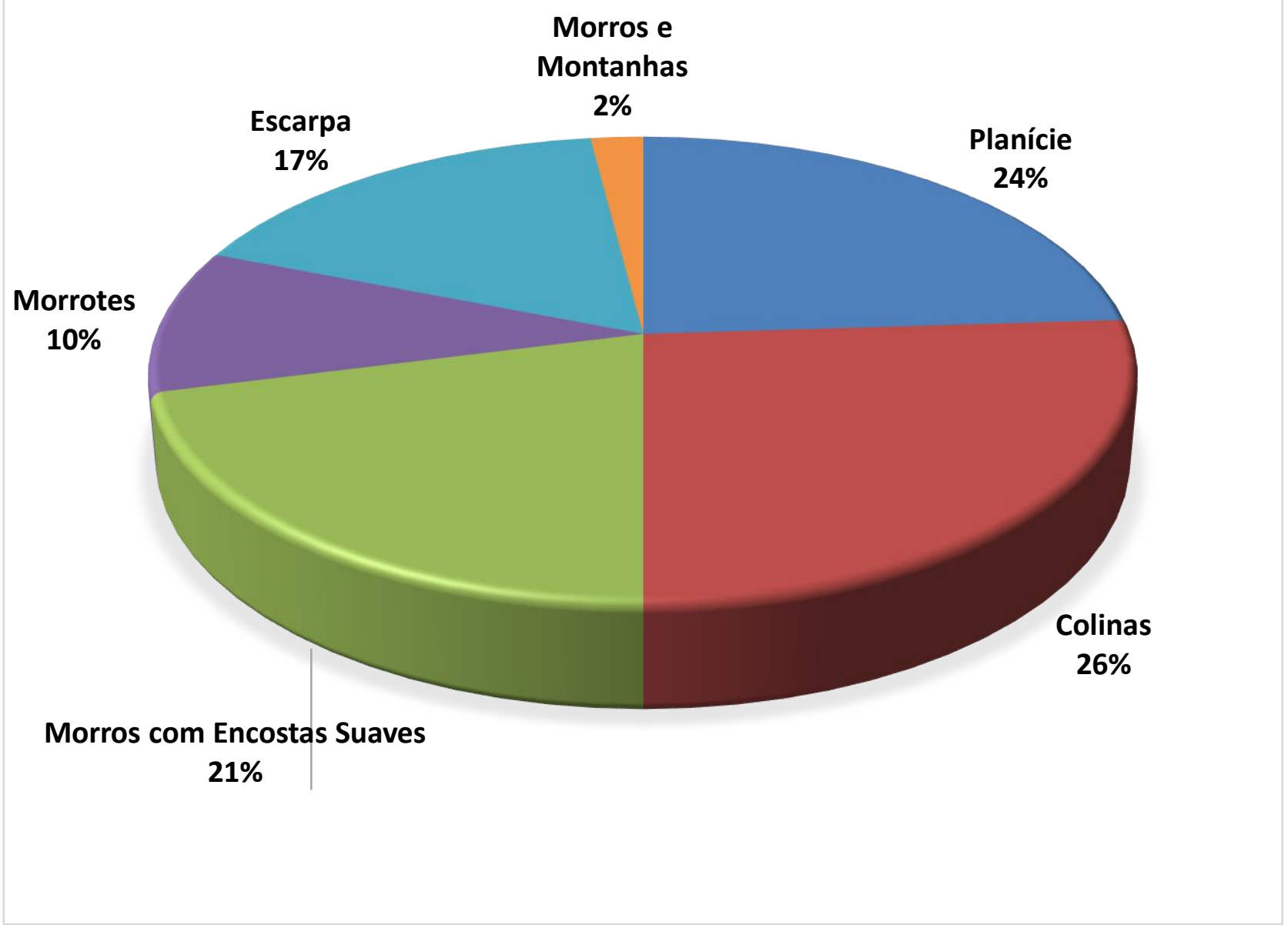

Figura 4 - Proporção em área ocupada por compartimento geomorfológico na APA do rio Machado - MG.

Fonte - Autores, 2019.

As tabelas 2 e 3, apresentam a síntese dos resultados obtidos para a hipsometria e a clinografia da bacia, respectivamente.

De acordo com a hipsometria (Figura 5A), de sul para norte, ocorre uma superfície de cimeira que varia de 1.134 a $1.475 \mathrm{~m}$ onde o rio Machado, principal drenagem da área, em seu trecho superior, tem direção geral S-N. Neste trecho, o mapa clinográfico (Figura 5B), mostra a predominância de declives que variam de 0 a $25 \%$ associados às vertentes que acompanham o rio Machado e o ribeirão Machadinho do Campo. Em seguida, o rio Machado inflete-se para SE-NW quando recebe na margem direita o ribeirão Machadinho do Campo e muda bruscamente seu trajeto na direção NNE em cotas topográficas mais baixas, que variam de 759 a 857m e declives mais altos variando de 36 a 60\%. É importante ressaltar a presença de knickpoints neste trecho do rio Machado, identificado como degrau ao longo do perfil longitudinal do rio (Figura 6), com desnível de 400m. De acordo com Crosby e Wipple (2004), knickpoints são degraus topográficos associados a dinâmica de ajustamento de canais fluviais. 
Tabela 3 - Síntese da hipsometria com as faixas altimétricas da APA do rio Machado.

\begin{tabular}{cl}
\hline $\begin{array}{c}\text { FAIXAS } \\
\text { ALTIMÉTRICAS }\end{array}$ & \multicolumn{1}{c}{ DOMÍNIO GEOMORFOLÓGICO } \\
\hline $750-857 \mathrm{~m}$ & $\begin{array}{l}\text { O trecho inferior da bacia, ocorre o domínio dos compartimentos de Colinas. E de } \\
\text { Planícies. Nos níveis altimétricos mais baixos, os vales e as planícies assumem } \\
\text { sedimentação expressiva do rio Machado e seus tributários das margens esquerda e direita. }\end{array}$ \\
$857-989 \mathrm{~m}$ & $\begin{array}{l}\text { Corresponde a pequenos trechos de fragmentos de compartimentos mais elevados como } \\
\text { escarpas e morros que delimitam a borda da bacia. } \\
\text { Esta faixa altimétrica corresponde aos domínios das serras do Cantagalo, da Bela Vista, do } \\
\text { Cafundó e do Cardoso, expondo um degrau topográfico. O compartimento de Colinas } \\
\text { predominantes ao sul, é delimitado por cristas retilíneas que marcam a presença de } \\
\text { compartimentos de Morros e Montanhas e Morros delimitando uma área mais deprimida } \\
\text { (faixas altimétricas mais baixas). } \\
\text { Corresponde aos relevos elevados da área, constituindo-se em relevos de cimeira. } \\
\text { Predominam compartimentos de colinas, seguidas por morros e morrotes isolados, além } \\
\text { do compartimento de planície do rio Machado. }\end{array}$ \\
\hline
\end{tabular}

Fonte - Autores, 2019

Tabela 4 - Síntese da clinografia com as faixas de declividades da APA do rio Machado.

\begin{tabular}{cl}
\hline $\begin{array}{c}\text { FAIXAS DE } \\
\text { DECLIVIDADES }\end{array}$ & \multicolumn{1}{c}{ DOMÍNIO GEOMORFOLÓGICO } \\
\hline $0-25 \%$ & $\begin{array}{l}\text { Corresponde as planícies dos principais rios da bacia e aos relevos mais suaves, no caso } \\
\text { as vertentes dos compartimentos das colinas. } \\
\text { Corresponde ao trecho médio e inferior da bacia compostos pelos compartimentos de } \\
\text { morros com encostas suaves, morrotes. Nestes compartimentos as vertentes apresentam } \\
\text { um grau de declive maior. }\end{array}$ \\
& $\begin{array}{l}\text { As duas faixas reunidas, de 36 a 45\% e de 46 a 60\%, correspondem aos trechos de } \\
\text { vertentes escarpadas dos compartimentos de morros e montanhas, morros com encostas } \\
\text { suaves, escarpas e morrotes isolados. Estes declives associam-se às principais serras da } \\
\text { bacia. }\end{array}$
\end{tabular}

Fonte: Autores, 2019.
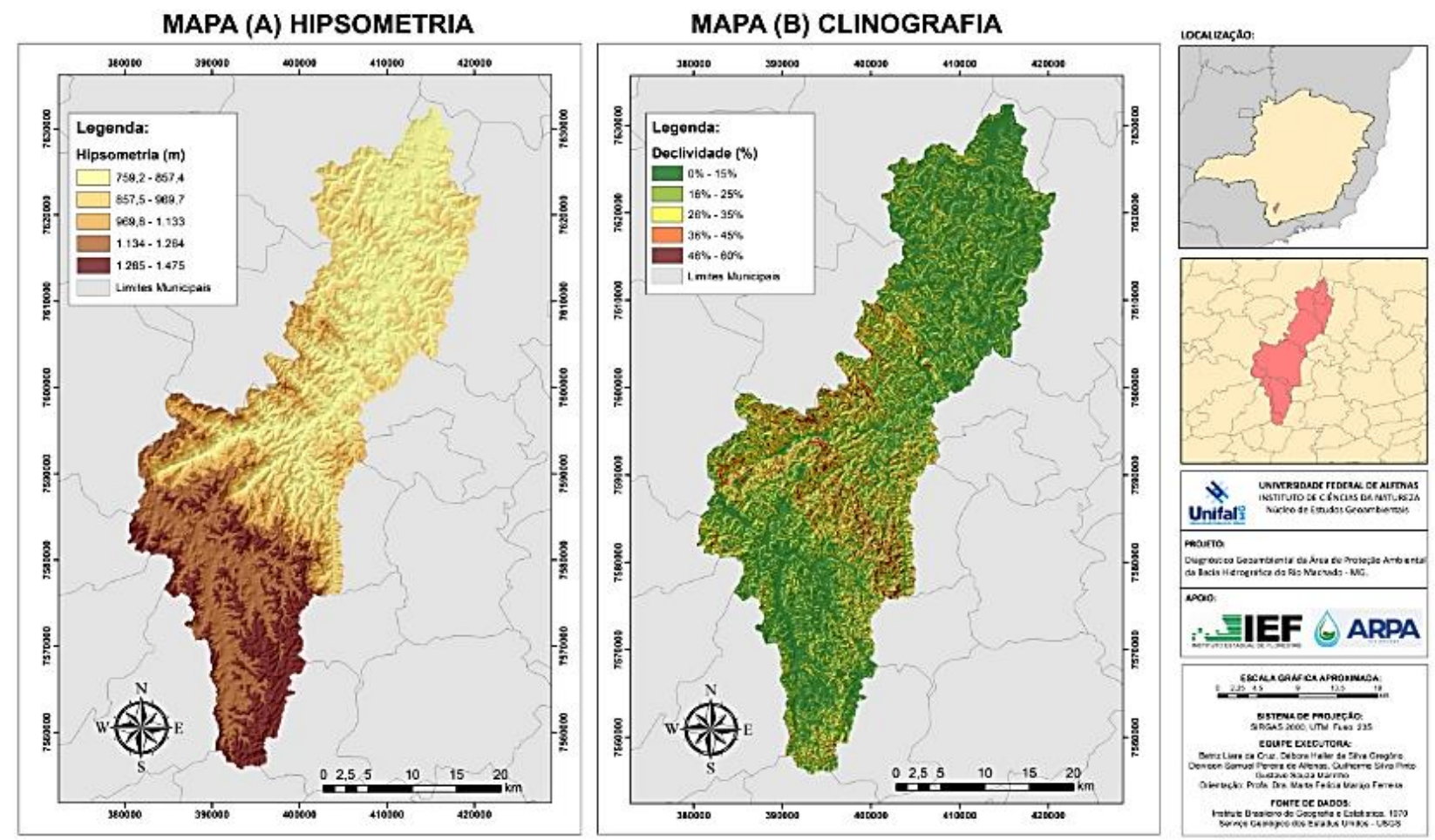

Figura 5 - Hipsometria (A) e Clinografia (B) da APA do rio Machado.

Fonte: Autores, 2019. 
RIO MACHADO

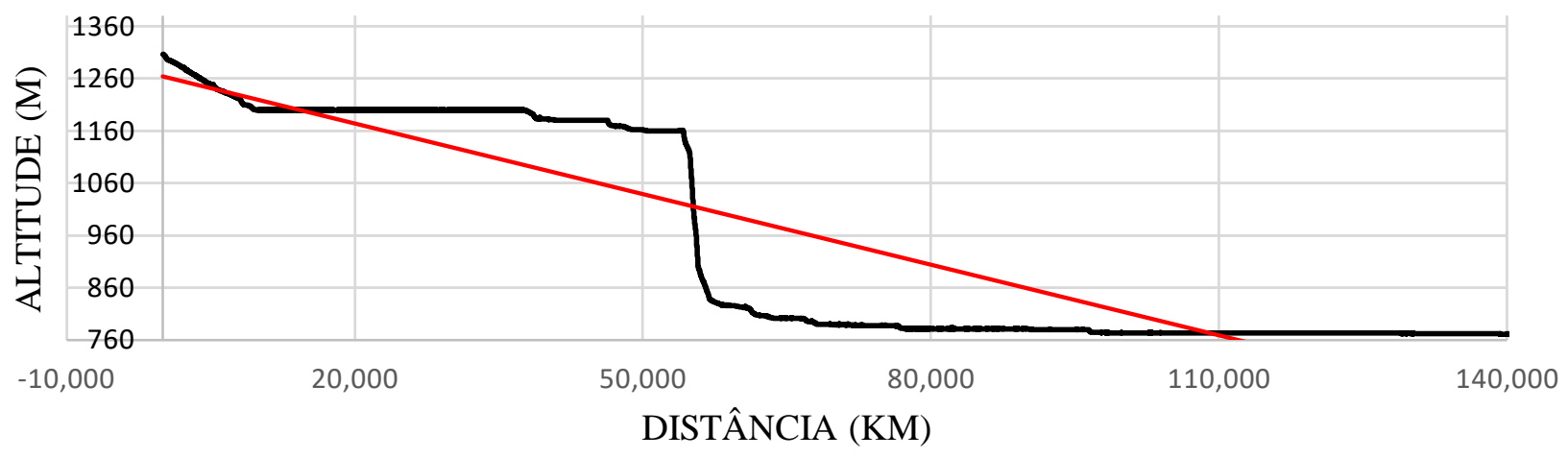

Figura 6 - Perfil Longitudinal do Rio Machado.

Fonte - Autores, 2019.

Os principais escarpamentos presentes na bacia (Compartimento de Escarpas) encontramse vinculados às Serras da Ponte e da Picada que mostram controle estrutural de direção NNE. As escarpas das Serras da Ponte (Figura 7) e da Picada associadas a Morros com Encostas Suaves, Morros e Montanhas e Morrotes, condicionam o encaixamento e o paralelismo do rio Machado e do ribeirão da Água Limpa, respectivamente (Figura 8). Além delas, ocorrem cristas retilíneas comandadas pelas Serras do Cantagalo, Bela Vista, Cafundó e Cardoso, principais divisores hidrográficos. A principal característica destas escarpas é o grau de dissecação com a presença de cursos d'água de $1^{\mathrm{a}}$. e $2^{\mathrm{a}}$. ordem que descem em direção aos eixos principais de drenagem. É importante destacar taxas de denudação mais elevadas nas áreas altimétricamente mais rebaixadas.

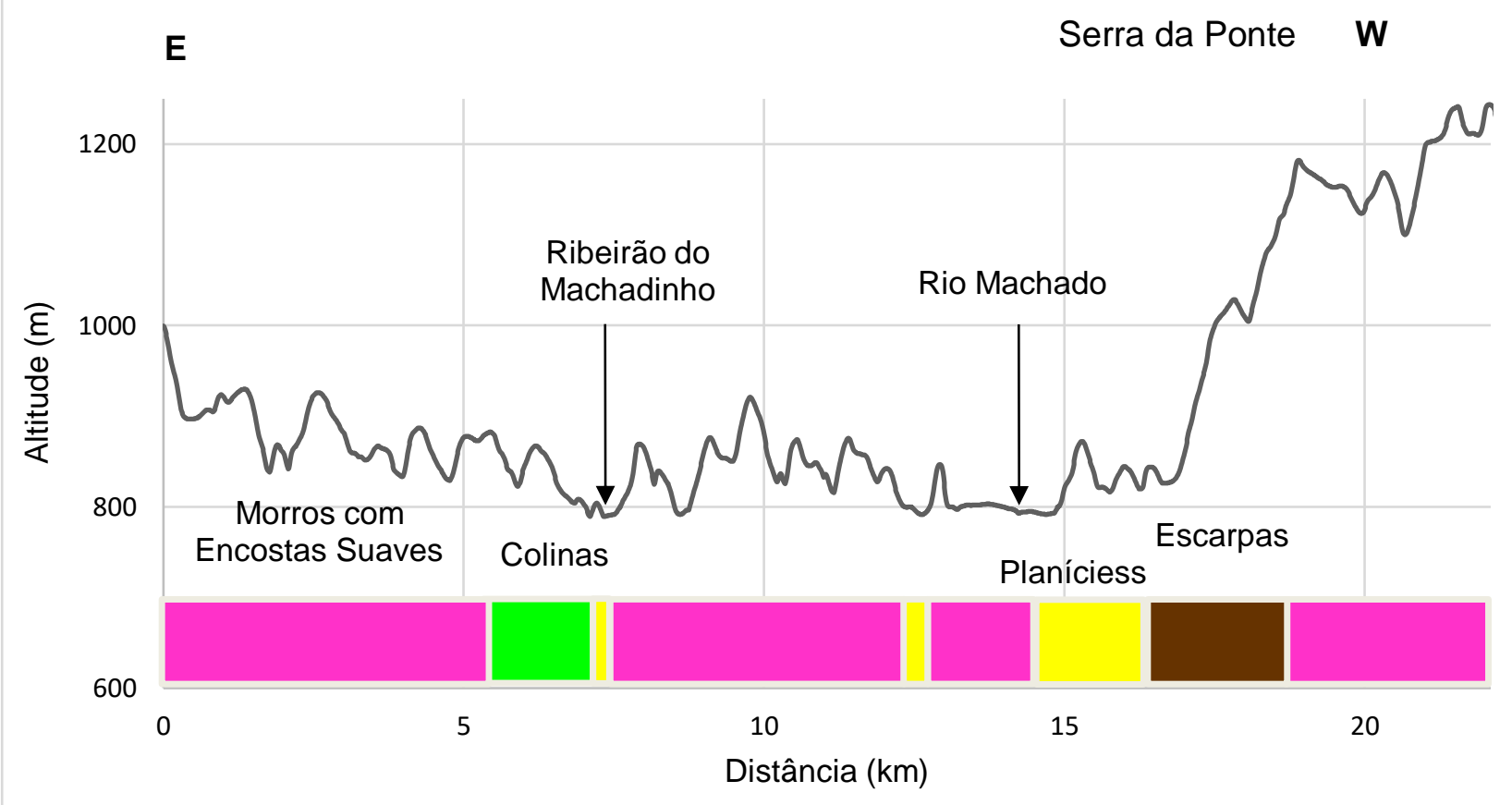

Figura 7 - Perfil topográfico E-F, em que se distingue a predominância dos compartimentos de Morros e a escarpa da Serra da Ponte.

Fonte - Autores, 2019. 


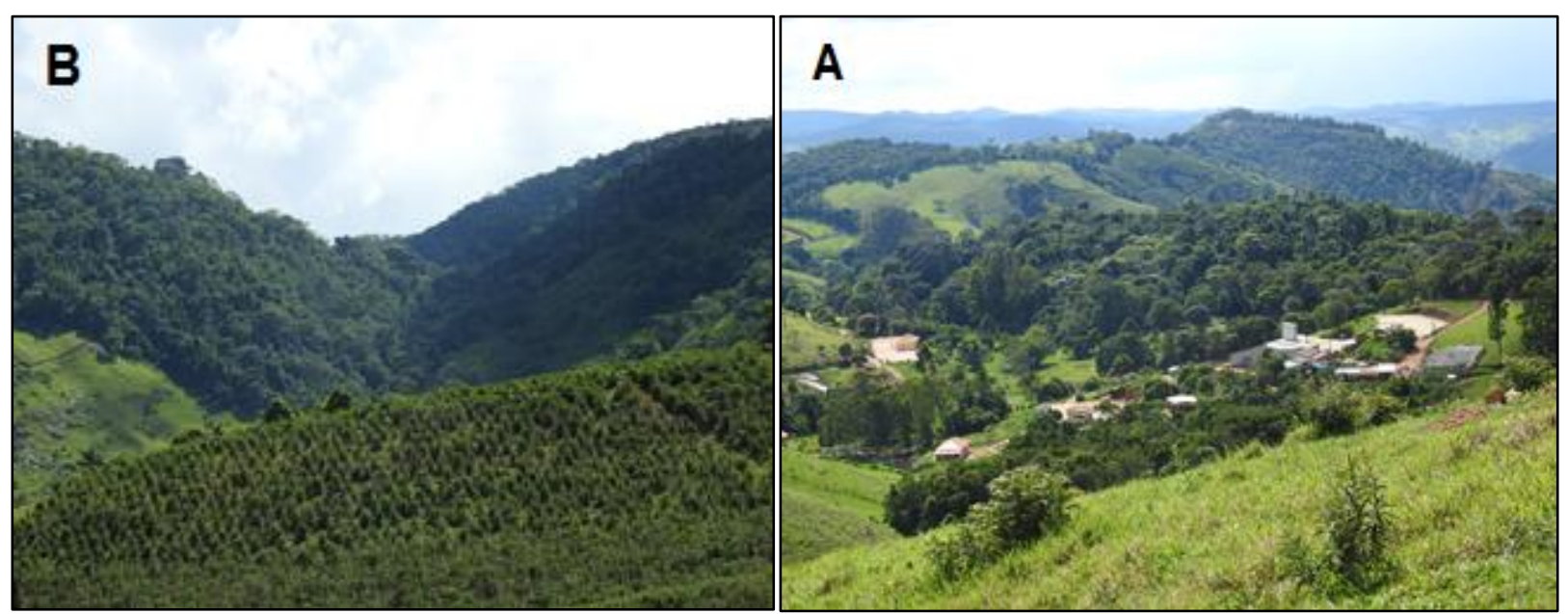

Figura 8 - A e B, Compartimentos de Morros com Encostas Suaves e vales em "V".

Fonte - Autores, 2019.

Neste trecho, associado ao desnivelamento altimétrico e condicionado pela escarpa da Serra da Ponte, o rio apresenta forte encaixamento, traçado retilíneo e degrau topográfico (knickpoint) indicado pela presença de queda d'água (Figura 9). O controle litológico de rochas do Complexo Pinhal é assinalado pela ocorrência de Migmatitos com estruturas diversas granodioríticos a predominantemente graníticos rosados, cinzentos e esbranquiçados, conforme estudos de Fiori (1979) e Artur (1988). Neste trecho, Artur (op. cit.) mapeou a ocorrência de falha de empurrão que pode estar condicionando o rio Machado. Lima et al. (2010) em seu estudo, também ressalta a presença de falha e a forte influência desta no encaixamento do rio.
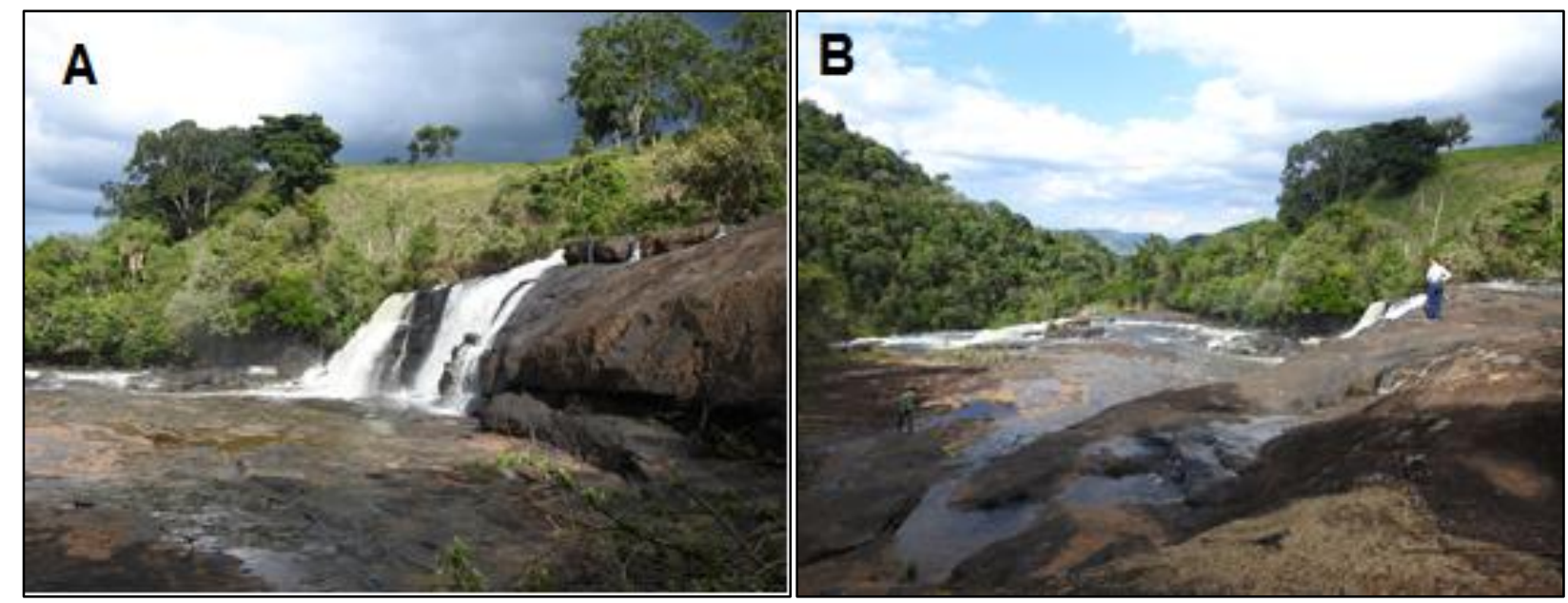

Figura 9 - A e B, Knickpoint do rio Machado. Presença de migmatitos.

Fonte - Autores, 2019.

O perfil longitudinal do rio Machado (Figura 6), demonstra um comportamento anômalo entre os trechos superior e médio. O trecho superior apresenta cota altimétrica que se inicia em $1307 \mathrm{~m}$ até $1160 \mathrm{~m}$ - este último valor associado ao knickpoint do perfil - tendo, portanto, amplitude 
altimétrica de $147 \mathrm{~m}$, enquanto que no trecho médio em direção ao trecho inferior, cotas de $1160 \mathrm{~m}$ até $760 \mathrm{~m}$, respectivamente, chegam à amplitude altimétrica de $400 \mathrm{~m}$.

Para Acklas Jr. et al. (2003), a curva quando apresenta desajuste, para cima ou para baixo, comprova uma anomalia morfométrica. Para os autores, estes desajustes podem ser interpretados por meio da confluência de grandes tributários que promovem uma sedimentação expressiva; por alterações no nível de base; na existência de substrato rochoso heterogêneo ou também atribuídos à neotectônica, com trechos em subsidência ou soerguimento. Esta anomalia verificada por meio do perfil longitudinal do rio, é confirmada também pelo trabalho desenvolvido por Lima et al. (2010).

De maneira geral, o comportamento morfogenético de uma bacia hidrográfica em seu trecho superior, mostra o predomínio de canais fluviais que possuem capacidade erosiva para remover os materiais intemperizados e transportá-los para trechos mais baixos, comprovando a presença de vales encaixados e em "V". Contudo, a bacia analisada demonstra um desvio deste padrão. O que se verifica na área é a ocorrência marcante do Compartimento de Colinas, que gradam de pequenas a amplas, com baixa amplitude topográfica e declives menores, às quais se associam às superfícies agradacionais, com forte sedimentação vinculadas ao Compartimento de Planícies do rio Machado e do ribeirão Machadinho do Campo (tributário da margem direita do rio Machado) delineando a ocorrência de vales amplos conforme o mapa geomorfológico da Figura 3.

A bacia do rio Machado está localizada no Planalto do Cervo, sendo este caracterizado como um bloco inclinado no sentido NW, desenvolvendo rios subparalelos de direção predominante NNESSW e secundariamente NW (FERREIRA, 2001). A autora citada ressalta que outros elementos geomorfológicos encontrados neste trecho da bacia são canais retilíneos encaixados em estruturas com direção NNE como é o caso do rio Machado e do ribeirão Machadinho do Campo. Ao longo dos vales destes rios, ocorre a sul, o Compartimento de Morros, a leste o Compartimento de Morrotes e, no centro, o predomínio do Compartimento de Colinas (Figura 10) em superfícies altimétricas que variam de 1.200 a 1.300m, conforme o perfil topográfico da Figura 11.

É possível verificar neste perfil a ocorrência marcante do Compartimento de Colinas como superfície de cimeira a oeste, onde o rio Machado tem seu fluxo meandrante adentrando a planície aluvionar. A leste, a Serra do Cantagalo com 1.350m de altitude, delimita um degrau topográfico ocorrendo os Compartimentos de Morrotes, Morros e Montanhas e Morros com Encostas Suaves, onde se instala o ribeirão do Machadinho a $880 \mathrm{~m}$. Os vales passam a ser assimétricos e em "V”, sendo o rio Machado, o ribeirão Machadinho e o ribeirão Pinhalzinho - ambos tributários da margem direita do rio Machado - os principais níveis de base. Localizados nestes compartimentos estão os municípios de Poço Fundo e Machado. Nas proximidades da cidade de Machado, o controle litológico exercido pelas rochas Granulíticas do Complexo Silvianópolis condicionando relevos mais elevados como o Compartimento de Morros com Encostas Suaves. 

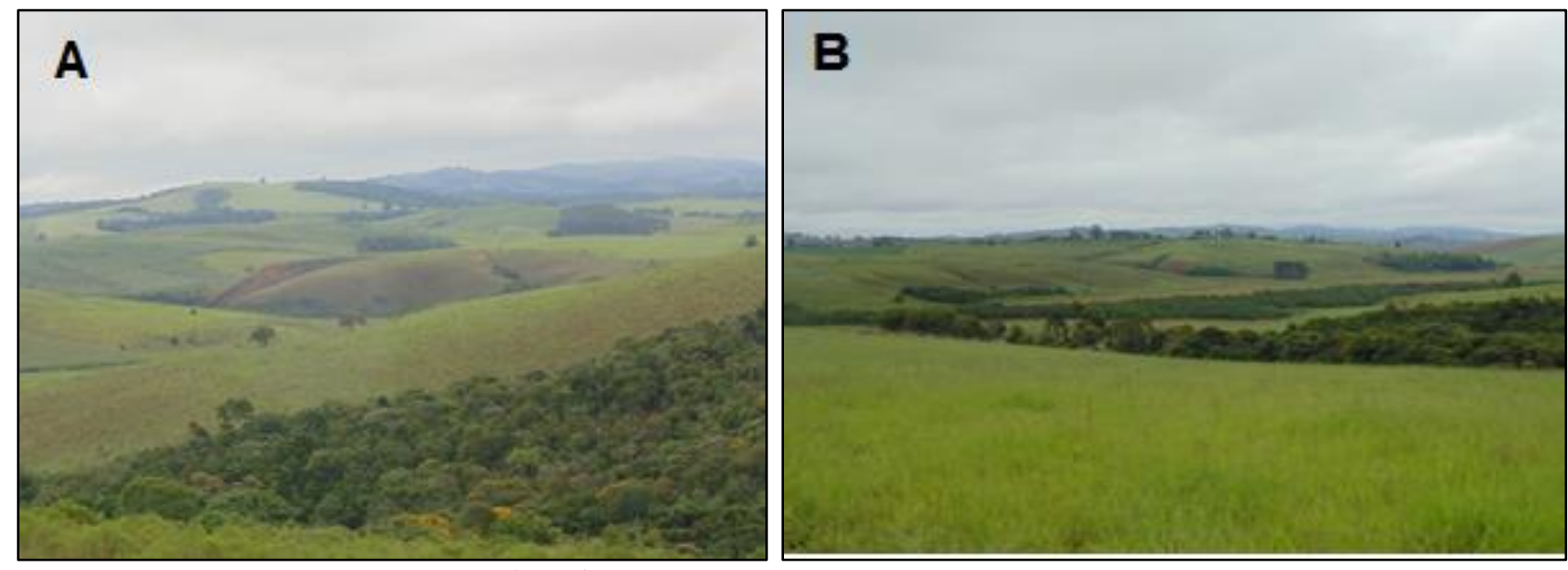

Figura 10 - A e B - Compartimento de Colinas no trecho superior da bacia do rio Machado. Superfície de cimeira com altitudes entre 1200 a $1320 \mathrm{~m}$.

Fonte - Autores, 2019.

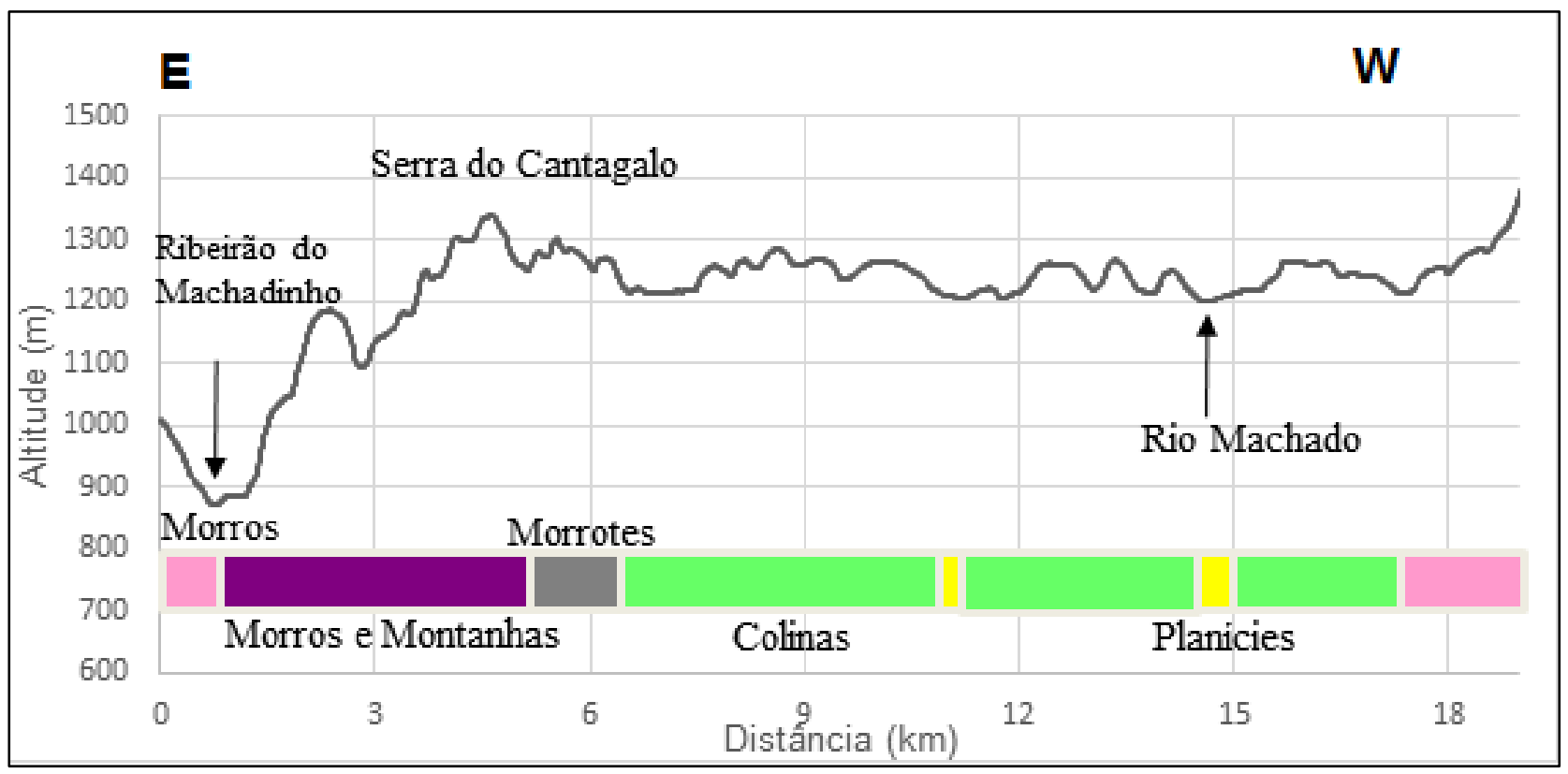

Figura 11 - Perfil topográfico C-D, em que se distingue a predominância de Colinas a oeste, Morrotes, Morros $\boldsymbol{e}$ Montanhas e Morros com Encostas Suaves a leste.

Fonte - Autores, 2019.

Em direção ao trecho inferior da bacia, a partir da cidade de Machado, o Compartimento de Colinas assume novamente o protagonismo, com altitudes em torno de 750 a $857 \mathrm{~m}$. O controle litológico é exercido pelas rochas do Complexo Amparo que, de acordo com Artur (1988) são Migmatitos de estruturas diversas e frequentes Gnáisses migmatíticos. Fiori (1979) atribui a presença de rochas do tipo Gnaisses fitados e bandeados ao Complexo Amparo.

Há o predomínio de vales de fundo chato, com expressiva sedimentação na planície do rio Machado (Figura 12) e nos ribeirões Ponte Alta, do Macuco, Urutum, localizados na margem direita do rio Machado, além dos da margem esquerda, córregos Caiana e da Lage. A baixa declividade das planícies entre 0 a 15\%, forma áreas aplanadas onde dominam inundações periódicas, promovendo ampla acumulação e deposição de sedimentos. 


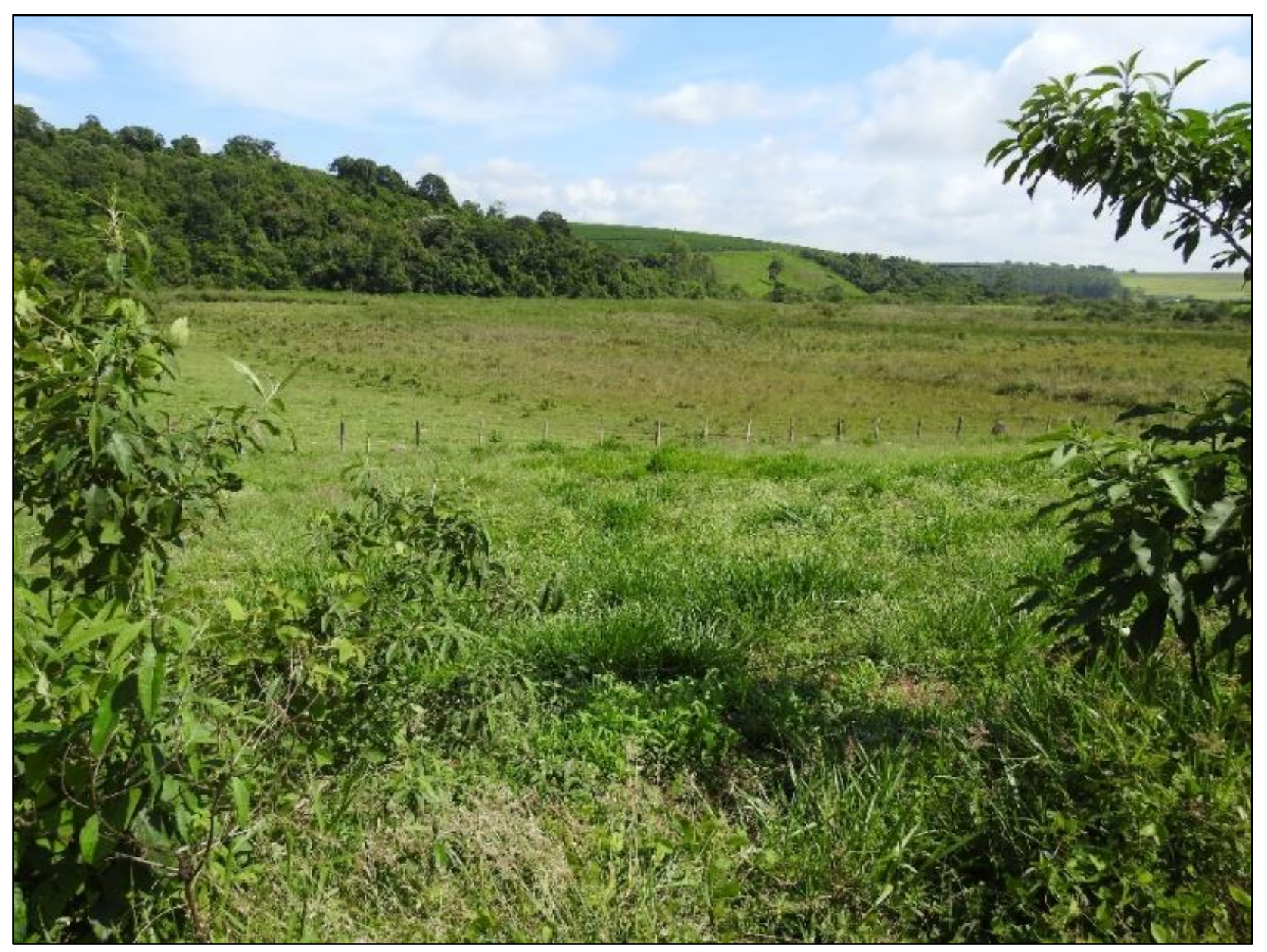

Figura 12 - Planície do rio Machado no Compartimento de Colinas localizado no trecho inferior do rio. Fonte - Autores, 2019.

\section{CONSIDERAÇÕES FINAIS}

A APA da bacia hidrográfica do rio Machado se encaixa no modelo de Unidade de Uso Sustentável, a qual tem como finalidade compatibilizar a conservação da natureza com o uso sustentável dos recursos naturais. A compartimentação geomorfológica proposta para a bacia do rio Machado demonstrou a existência de seis compartimentos geomorfológicos que se encontram condicionados pelo controle litoestrutural, promovendo a dissecação do relevo.

A combinação entre métodos convencionais de mapeamento geomorfológico baseados em trabalhos de campo e técnicas analógicas de interpretação visual, juntamente com técnicas de geoprocessamento, permitiram a obtenção de produtos cartográficos de qualidade superior.

Para apoio da análise geomorfológica considerou-se a elaboração dos mapas hipsométrico e clinográfico que permitiram a visualização de superfícies morfológicas erosivas, além dos compartimentos de relevo com superfícies de vertentes com maiores e/ou menores declives, corroborando com os resultados do mapa geomorfológico.

Resultados alcançados a partir do mapeamento geomorfológico realizado, permitem afirmar que a bacia apresenta um degrau topográfico entre os trechos superior e médio, com variação 
amplitudinal de 400m, assinalando a presença de superfícies altimétricamente mais elevadas ao sul (trecho superior da bacia), e superfícies rebaixados ao norte da área (trechos médio e inferior da bacia). A sul, ocorre o domínio do Compartimento de Colinas, sustentadas por rochas do Complexo Pinhal, caracterizadas por Migmatitos de estruturas diversas e Granitos.

O rio Machado mostra canal meandrante nesta superfície, acumulando ampla sedimentação aluvionar, desenhando vales amplos. Para o norte, o desnivelamento topográfico revelado pela anomalia do perfil longitudinal do rio, coincide com a organização da rede hidrográfica do rio Machado que se aloja em superfície altimétricamente mais baixa, com traçado retilíneo, condicionado por falha, e vales em "V". Este degrau apresenta características morfológicas erosivas ocorrendo os Compartimentos de Morros e Montanhas, Morros com Encostas Suaves e Morrotes. Este conjunto de relevos de amplitudes mais elevadas, marcam a presença de cristas retilíneas das Serras do Cantagalo, da Bela Vista, do Cafundó e do Cardoso. Estas serras apresentam escarpamentos em fronts dissecados por canais de $1^{\mathrm{a}}$. e $2^{\mathrm{a}}$. ordem. A litologia citada acima, exerce controle litológico nas cristas e escarpas e na presença de afloramentos expostos.

Em direção a jusante, as rochas pertencentes ao Complexo Amparo do tipo Gnaisses fitados e bandeados e Gnáisses Migmatíticos controlam a ocorrência de superfície morfológica rebaixada, onde dominam o Compartimento de Colinas e as planícies do rio Machado e de seus tributários da margem direita e esquerda. $\mathrm{O}$ rio Machado se mostra meandrante com expressiva sedimentação em vales amplos.

O mapa geomorfológico é um documento de grande potencialidade para uso em pesquisas interdisciplinares, para o zoneamento ambiental, bem como para o plano de manejo da APA, além de fornecer subsídios para a administração pública dos municípios integrantes da bacia do rio Machado.

\section{AGRADECIMENTOS}

Os autores agradecem o apoio e subsídios fornecidos pela Agência Regional de Proteção Ambiental da Bacia do Rio Grande (ARPA) que financiou o Projeto "Diagnóstico geoambiental da APA da bacia hidrográfica do rio Machado/MG”, do Instituto Estadual de Florestas (IEF) e da Universidade Federal de Alfenas (UNIFAL-MG). Agradecem também a colaboração de Fernando Aryson Milan, do Instituto Estadual de Florestas (IEF) no acompanhamento dos trabalhos de campo.

\section{REFERÊNCIAS}

ACKLAS JUNIOR, R.; ETCHEBEHERE, M. L. C.; CASADO, F. C. Análise de perfis longitudinais de drenagens do Município de Guarulhos para a detecção de deformações neotectônicas. Revista UnG - Geociências, v. 8, n. 6, p. 64-78, 2003. 
ALMEIDA, S. H. S. Estruturação tectônica da borda norte da Cunha de Guaxupé na região de Alfenas - MG. 1997. 156p. Dissertação (Mestrado em Geologia Regional) - Instituto de Geociências e Ciências Exatas, Universidade Estadual Paulista, Rio Claro, 1997.

ALVES, H. M. R.; BERNARDES, T.; SILVEIRA, M. A.; NICOLELlA, G.; VIEIRA, T. G. C. Delimitação de um território potencial para a produção de cafés de qualidade diferenciada dos municípios de Campestre, Machado e Poço Fundo, MG. In: SIMPÓSIO DE PESQUISA DOS CAFÉS DO BRASIL. 5., 2007, Águas de Lindóia. Anais... Águas de Lindóia: EMBRAPA CAFÉ, 2007. p. 9-25.

ALVES, H. M. R.; LACERDA, M. P. C.; VIEIRA, T. G. C. Caracterização de agroecossistemas cafeeiros nas principais regiões produtoras do estado de Minas Gerais. In. SIMPÓSIO BRASILEIRO DE SENSORIAMENTO REMOTO. 11., 2003, Belo Horizonte. Anais... Belo Horizonte: INPE, 2003. p. 11-17.

ARTUR, A. C. Evolução policíclica da infra-estrutura da porção sul do estado de Minas Gerais e regiões adjacentes do estado de São Paulo. 1988. 246f. Tese (Doutorado em Geociências) Instituto de Geociências, Universidade de São Paulo, São Paulo, 1988.

BRASIL. Lei Federal n. 9.985, de 18 de julho de 2000. Regulamenta o art. 225, § 1o, incisos I, II, III e VII da Constituição Federal, institui o Sistema Nacional de Unidades de Conservação da Natureza e dá outras providências. Presidência da República - Casa Civil, Brasília, DF, 18 jul. 2000.

CARdoso, F. J. Ação Pública em Terrenos de Fundo de Vale - Estudo de uma bacia Hidrográfica do Município de Alfenas. 2003. Dissertação (Mestrado em Urbanismo) - Centro de Ciências Exatas Ambientais e de Tecnologia, Pontifícia Universidade Católica. Campinas, 2003.

CAVAlCANTE, J. C.; CUNHA, H. C. S.; CHIEREGATI, L. A.; KAEFER, L.; ROCHA, J. M.; DAITX, E. C.; COUTINHO, M. G. N.; YAMAMOTO, K.; DRUMOND, J. B. V.; ROSA, D. B.; RAMALHO, R. Projeto Sapucaí. Brasília, DNPM. (Série Geologia, 4), (Relatório Final), 1979. $619 \mathrm{p}$.

CROSBY, B. T.; WHIPPLE, K. X. The role of knickpoints in the Waipaoa River: basin-wide communicator of base level fall or consequence of an erosional threshold? Geological Society of America, v. 36, n. 5, p. 305, 2004.

CUNHA, C. M. L.; MENDES, I. A.; SANCHEZ, M. C. A Cartografia do Relevo: Uma Análise Comparativa de Técnicas para a Gestão Ambiental. Revista Brasileira de Geomorfologia, v. 4., n. 1, p. 01-09, 2003.

DEMECK, J. Generalization of Geomorphological Maps. In: Proceedings of the meeting of the IGU-comission on applied geomorphology, sub-comission on geomorphology mapping. Progress made in geomorphological mapping. Breno and Bratislava, p. 63-72, 1967.

FERREIRA, M. F. M. Geomorfologia e análise morfotectônica do alto vale do Sapucaí - Pouso Alegre (MG). 2001. 276f. Tese (Doutorado) - Instituto de Geociências e Ciências Exatas, Universidade Estadual Paulista, Rio Claro, 2001.

FIORI, A. P. Geologia da região de Pouso Alegre - Machado: análise estrutural de dobramentos superpostos. 1979. 210f. Tese (Doutorado) - Instituto de Geociências, Universidade de São Paulo, São Paulo, 1979. 
GUERRA, A. J. T.; MARÇAL, M. S. Geomorfologia Ambiental. 1. ed. Rio de Janeiro: Bertrand Brasil, 2006. 190p.

JOLY, F. Point de vue sur la géomorphologie. Annales de Géographie, v. 86, n. 477, p. 522-541, 1977.

LIMA, H. C.; DORANTI, C.; HACHSPACHER, P. C.; RIBEIRO, M. C. S.; RIBEIRO, L. F. B. Análise morfométrica da rede de drenagem da bacia do rio do Machado-MG. Sociedade \& Natureza, Uberlândia, v. 22, n. 1, p. 23-34, 2010.

MARQUES, J. S. Ciência Geomorfológica. In: GUERRA, A. T.; CUNHA, S. B. (Orgs.) Geomorfologia: Uma atualização de bases e conceitos. São Paulo: Bertrand Brasil, 1994. p. 23-50.

PIRES NETO, A. G. As abordagens sintético-histórica e analítico-dinâmica: uma proposição metodológica para a geomorfologia. 1991. 302p. Tese (Doutorado) - Departamento de Geografia, Universidade de São Paulo, São Paulo, 1991.

RODRIGUES, C. Geomorfologia Aplicada: Avaliação de Experiências e de Instrumentos de Planejamento Físico-Territorial e Ambiental Brasileiros. 1997. 280p. Tese (Doutorado em Geografia Física) - Departamento de Geografia da Faculdade de Filosofia, Letras e Ciências Humanas, Universidade de São Paulo, São Paulo, 1997.

ROSS, J. L. S. Geomorfologia Ambiental. In: CUNHA, S. B.; GUERRA, A. J. T (Orgs). Geomorfologia do Brasil. Rio de Janeiro: Bertrand Brasil, 2003. p. 351-388.

ROSS, J. L. S. Geomorfologia Ambiente e Planejamento. 1. ed. São Paulo: Contexto, 1990. 86p.

ROSS, J.; MOROZ, I. Mapa geomorfológico do estado de São Paulo. Revista do Departamento de Geografia, São Paulo, v. 10, p. 10-58, 1996.

ROSS, J. L. S. O Registro Cartográfico dos Fatos Geomorfológicos e a Questão da Taxonomia do Relevo. Revista do Departamento de Geografia, São Paulo, v. 6, p. 17-29, 1992.

SAADI, A. Ensaio sobre a Morfotectônica de Minas Gerais. 1991. 285p. Tese (Professor Titular) - Instituto de Geociências, Universidade Federal de Minas Gerais, Belo Horizonte, 1991.

SILVA, G. P. R.; ETCHEBEHERE, M. L.; SAAD, A. R.; FRANCO-MAGALHÃES, A. O. B. Análise de perfis segmentados de drenagem para a avaliação morfotectônica na bacia hidrográfica do alto rio Jaguari (SP-MG). São Paulo, UNESP, Geociências, v. 31, n. 2, p. 259-271, 2012.

TRICART, J. Principes et méthodes de la géomorphologie. Paris: Masson, 1965. p. 598-601

TRICART. J. A geomorfologia nos estudos integrados na ordenação do meio natural. Bo1etim Geográfico, Rio de Janeiro, v. 34, n. 251, p. 15-42, 1976. 